OPEN ACCESS

Edited by:

Mohamed Hijri,

Université de Montréal, Canada

Reviewed by:

Birinchi Kumar Sarma,

Banaras Hindu University, India

Syed Riyaz-ul-Hassan,

Indian Institute of Integrative Medicine

(CSIR), India

*Correspondence:

Chirlei Glienke

ch.glienke@gmail.com

Specialty section:

This article was submitted to

Fungi and Their Interactions,

a section of the journal

Frontiers in Microbiology

Received: 02 April 2018

Accepted: 19 June 2018

Published: 24 July 2018

Citation:

Noriler SA, Savi DC, Aluizio $R$, Palácio-Cortes AM, Possiede YM and Glienke C (2018) Bioprospecting and

Structure of Fungal Endophyte Communities Found in the Brazilian

Biomes, Pantanal, and Cerrado.

Front. Microbiol. 9:1526.

doi: 10.3389/fmicb.2018.01526

\section{Bioprospecting and Structure of Fungal Endophyte Communities Found in the Brazilian Biomes, Pantanal, and Cerrado}

\author{
Sandriele A. Noriler ${ }^{1}$, Daiani C. Savi ${ }^{2}$, Rodrigo Aluizio ${ }^{2}$, Angela M. Palácio-Cortes ${ }^{3}$, \\ Yvelise M. Possiede ${ }^{4}$ and Chirlei Glienke ${ }^{2 *}$ \\ ${ }^{1}$ Department of Basic Pathology, Federal University of Paraná, Curitiba, Brazil, ${ }^{2}$ Department of Genetics, Federal \\ University of Paraná, Curitiba, Brazil, ${ }^{3}$ Department of Zoology, Federal University of Paraná, Curitiba, Brazil, ${ }^{4}$ Department of \\ Biology, Federal University of Mato Grosso do Sul, Campo Grande, Brazil
}

Medicinal plants have been recognized as hosts of high diverse endophytic microorganisms, including fungi that produce secondary metabolites with biological activity. Two biomes in Brazil, Pantanal (wetland), and Cerrado (savannah), are known as biodiversity hotspots, and despite their importance as a reservoir for several species, knowledge about the fungal biodiversity in these biomes is very limited. Fungal endophytic communities associated with leaves and petioles of the medicinal plants Vochysia divergens (from Pantanal) and Stryphnodendron adstringens (from Cerrado) were analyzed and studied for their antimicrobial activity against human and plant pathogens. A total of 1,146 isolates of endophytic fungi were obtained from plants collected in January and June of 2016 and grouped into 124 morphotypes. One isolate of each morphotype was identified by sequencing of internal transcribed spacer (ITS) region of the rDNA gene, which revealed the presence of 24 genera, including 3 possible new genera, and 48 taxa. Differences in the endophytic community according to the biomes were observed concerning the analyzed morphotypes. However, when we analyzed the diversity of genera and richness, they were similar for both plants, with Diaporthe, Phyllosticta, and Neofusicoccum as dominant genera. In addition, the community composition of $V$. divergens differs according to the analyzed plant tissues (petiole and leaf). These data suggested that both, the plant species and plant tissues play a role in the composition of endophytic community. As regards the biotechnological potential, 5 isolates showed activity against the phytopathogens Phyllosticta citricarpa, Colletotrichum abscissum, and Fusarium verticilioides, and 8 isolates showed high activity against clinical pathogens and were selected for the production of crude extract in different culture media. Extract from cultivation of Diaporthe sp. LGMF1548 and LGMF1583 and Neofusicoccum brasiliense LGMF1535 showed activity against methicillin-resistant Staphylococcus aureus, Klebssiella pneumonia, and 
Candida albicans. In addition, extracts of Diaporthe cf. heveae LGMF1631 inhibited 90\% of the mycelial growth of the $P$. citricarpa and $70 \%$ of $C$. abscissum and may represent an alternative to be used in the biological control of these phytopathogens. Future research will focus on the chemical characterization and structural elucidation of these bioactive compounds.

Keywords: Vochysia divergens, Stryphnodendron adstringens, natural antimicrobials, medicinal plants, Diaporthe

\section{INTRODUCTION}

In the last years, medicinal plants have gained great importance as a reservoir of new endophytic strains with biotechnological potential (Gomes et al., 2013; Köberl et al., 2013; Savi et al., 2018). The endophyte-host interaction can interfere with the plant growth, development, and defense against pathogens and insects (Murali et al., 2007; Santoyo et al., 2016). However, the endophytic community is highly variable and depends on several components, such as host species and environmental conditions (Dudeja and Giri, 2014). In this context, two Brazilian biomes are particularly prominent due to the biodiversity of the flora: the savannah (Cerrado) and the wetland (Pantanal).

The Pantanal is a wetland located in the center of South America, in the Upper Paraguay River Basin, characterized by the change between periods of flood and drought, and the flora diversity found in this biome may be the result of seasonality in this area (Junk et al., 1989). Floods can inundate $80 \%$ of the entire Pantanal, and by contrast, during the dry season, most flooded areas will be dry. The biodiversity of Pantanal constitutes a valuable natural resource, and it is recognized as one of the most important freshwater ecosystems in the world. However, the unsustainable land use in this biome has been harming this peculiar biodiversity (Alho and Silva, 2012), and effective alternatives to conservation are necessary, such as bioprospecting studies to associate an economic value to the diversity present in this area.

The Brazilian savannah (Cerrado) is a neighboring biome of Pantanal that biogeographically influences its biodiversity and hosts a huge diversity of flora (Silva and Bates, 2002). The Cerrado is classified as one of the most diverse places in the world (Myers et al., 2000), with an estimated composition of more than 6,000 vascular plant species (Oliveira-Filho and Ratter, 2002; Felfili and Fagg, 2007). The diversity composition is result of the adverse environmental conditions caused by the fire, which selects the vegetation, changing the dominant plant species (Felfili and Fagg, 2007).

As these biomes are located in unexplored transition areas and are subject to adverse climatic changes, they were declared as priority conservation areas by the Brazilian government. Studies in the Pantanal and Cerrado are usually on animal and plant biodiversity (Hyde and Soytong, 2008; Porras-Alfaro and Bayman, 2011). A very limited number of studies in these biomes are conducted on endophytic microorganisms, and most of them are focused on aspects of bioprospecting without community analysis (Carvalho et al., 2012; Glienke et al., 2012; Vieira et al., 2014; Savi et al., 2016; Gos et al., 2017; Hokama et al., 2017; Parpinelli et al., 2017; Sousa et al., 2017).
The environmental conditions and the composition of the plants present in the Pantanal and Cerrado represent an unrivaled variety of habitats, which can have a significant influence on the endophytic community. As there are no studies comparing the species richness and the endophytic community between these two biomes, some questions remain unclear: What is the taxonomic composition and diversity of these endophytic fungi? Is the endophytic community biome-specific? Is the diversity structured or spread among these neighboring biomes? What is the biotechnological potential of these endophytic fungi?

To address these questions, we analyzed and bioprospected the fungal endophytic community from two medicinal plants: Vochysia divergens Pohl (Vochysiaceae) and Stryphnodendron adstringens (Mart.) Coville (Fabaceae), found in Pantanal and Cerrado biomes, respectively. Vochysia divergens is considered as monodominant remaining during dry and flood season in the Pantanal (Junk et al., 2006) and S. adstringens is a native Cerrado species widely used in traditional medicine for its biological properties. These plants were selected according to the biome specificity, the medicinal properties and the lack of endophytic community studies.

\section{MATERIALS AND METHODS}

\section{Plant Material}

The leaves and petioles of $S$. adstringens and $V$. divergens were collected in January and June 2016 from two Brazilian biomes, Cerrado (Savanna) and Pantanal. The collection of leaves and petioles of $V$. divergens was carried out in Pantanal of Miranda River $\left(19^{\circ} 32^{\prime} 36.9^{\prime \prime} \mathrm{S} 57^{\circ} 02^{\prime} 21.8^{\prime \prime} \mathrm{W}\right)$, along of MS184 Road in Corumbá, Mato Grosso do Sul State, Brazil (Figure 1; were performed using R 3.4.4 R Core Team, 2017, source IBGE, 2004). The $S$. adstringens leaves and petioles were collected in Cerrado along the BR262 road $\left(20^{\circ} 18^{\prime} 10.8^{\prime \prime} \mathrm{S} 56^{\circ} 15^{\prime} 44.3^{\prime \prime} \mathrm{W}\right)$ in Miranda, Mato Grosso do Sul State, Brazil (Figure 1). The samples of the S. adstringens were collected from 10 plants in January and 23 in June, and the samples of $V$. divergens were collected from 8 plants in January and 24 in June. For both species, 10 leaves and 10 petioles were collected for each individual plant. The plant tissues were stored at $4^{\circ} \mathrm{C}$ and isolation was performed within $72 \mathrm{~h}$.

The January collection was used as a preliminary test for the epiphytic elimination protocol. The isolated endophytes of this collection were used only for bioprospecting and phylogenetic studies and were not included in the community analysis. With the optimized epiphytic elimination protocol, a second collection was performed in June, and the isolates obtained 


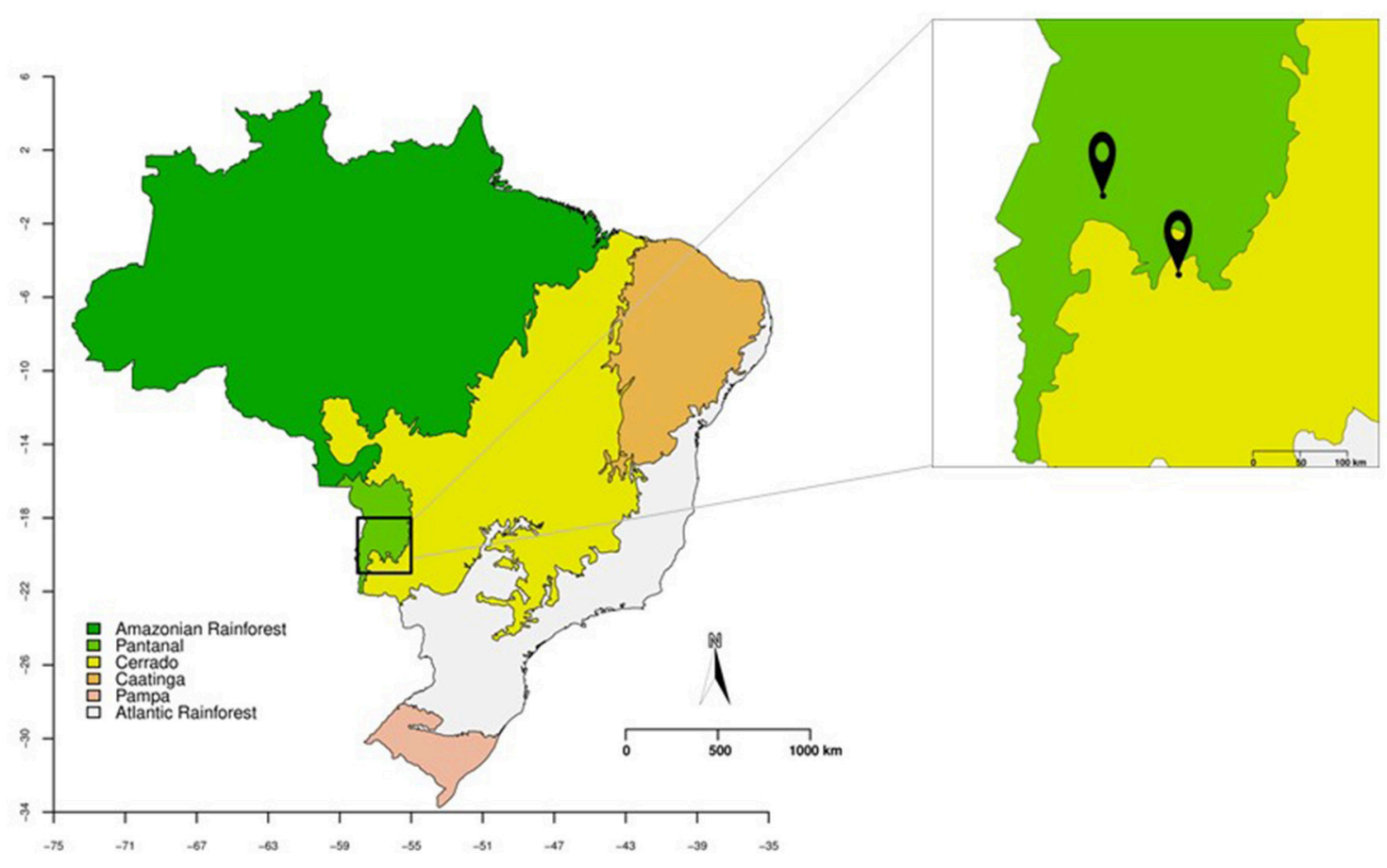

FIGURE 1 | Brazil map showing the Pantanal (in green) and Cerrado (in yellow) biomes. In the magnified box are represented the collecting points of leaves and petioles of Vochysia divergens (Pantanal) and Stryphnodendron adstringens (Cerrado).

were used for endophytic community evaluation, phylogeny, and bioprospecting studies.

\section{Isolation and Morphotyping}

The leaves and petioles, without lesions, from healthy plants, were used for endophytic fungi isolation using the 6 steps protocol described by Petrini (1986), with modifications: the leaves and petioles were submerged in autoclaved water for $1 \mathrm{~min}$, immersion in $70 \%$ ethanol $(\mathrm{v} / \mathrm{v})$ for $1,3 \mathrm{~min}$ in sodium hypochlorite $3 \%(\mathrm{v} / \mathrm{v}), 30 \mathrm{~s}$ in $70 \%$ ethanol $(\mathrm{v} / \mathrm{v})$, and then washed in sterilized distilled water for $1 \mathrm{~min}$. After surface sterilization, the samples were fragmented into 5 pieces of $8 \times 8 \mathrm{~mm}$ and aseptically transferred to plates containing potato dextrose agar (PDA), $\mathrm{pH}$ 5.8. The plates were incubated at $28^{\circ} \mathrm{C}$ for 30 days, and the endophytic growth was checked daily, the emerging mycelia were transferred to a new plate and stored at $4^{\circ} \mathrm{C}$ on PDA for further identification.

The isolation frequency (IF) of endophytes was calculated as the number of fragments from which one or more endophytic fungi were isolated, divided by the total number of fragments analyzed (Petrini et al., 1982). The isolates were assigned to morphotypes based on growth rate, colony color, hypha aspects, presence/absence and morphology of spores. One isolate from each morphotype was randomly selected for molecular identification and bioprospecting. For each isolate, a pure culture was obtained through single spore culture approach, according to Gilchrist-Saavedra et al. (2006). The isolates were deposited in the Laboratório de Genética de Microrganismos (LabGeM) culture collection, at the Federal University of Paraná, Brazil (http:// www.labgem.ufpr.br/).

\section{Isolates Identification}

Isolates were cultivated on PDA for 3 days at $28^{\circ} \mathrm{C}$, and genomic DNA extraction was performed according to Raeder and Broda (1985). Primers V9G (de Hoog and Gerrits van den Ende, 1998) and ITS4 (White et al., 1990) were used to amplify the internal transcribed spacer region (ITS) of the nuclear ribosomal RNA gene. PCR reaction was performed using Top Taq Master Mix (QIAGEN), purified with the Exol and FastAP enzymes (ThermoFisher Scientific, USA) and sequenced using the BigDye Terminator Cycle Sequencing Kit v 3.1 kit (Applied Biosystems, Foster City, CA, USA). DNA sequences were obtained on an ABI Prism 3500 sequencer (Applied Biosystems, Foster City, CA, USA). Chromatograms were inspected using MEGA 7 software (Kumar et al., 2015) and BioEdit 7.0.5.3 (Hall, 1999) and compared to sequences available in the NCBI / GenBank database (National Center for Biotechnology Information Http://www.ncbi.nlm.nih.gov/BLAST/) using the tool Blast, and comparing with the types strains found in MycoBank database (http://www.mycobank.org/).

The phylogenetic analyses were performed using sequences from the available type strains of each genus identified in addition to the sequences generated in this study. Alignments of DNA sequences were performed using the Mafft (Katoh and Toh, 2008; https://mafft.cbrc.jp/alignment/server/) and manually corrected when necessary in MEGA version 7 (Tamura et al., 2013). Phylogeny based on Bayesian inference was performed 
in MrBayes version 3.2.1 (Ronquist et al., 2011), using two parallel runs with one cold and three heated chains each, using the number of generations needed to reach split frequencies of $\leq 0.01$ and a sampling frequency set to every 100 generations. The posterior probability values were calculated after discarding the first $25 \%$ of the generated trees as burn-in. Resulting trees were plotted in FigTree v.1.4.2 (http://tree.bio.ed.ac.uk/software/ figtree/). The substitution model was selected for each genus using the MEGA software. All sequences obtained were deposited in GenBank, access codes listed in Table S1.

\section{Analysis of Endophytic Fungal Community}

Analyzes of the endophytic community were performed at genera and morphotypes levels, comparing fungal community in both plants, and between leaves and petioles tissues. To analyze the data a matrix of abundance was used, and plants with no endophyte recovered were removed from the analysis, as well as, those rare taxa that accomplished $<5$ percent of total abundance for genera and for morphotypes. The diversity index, total abundance, and richness were calculated based on the identified morphotypes and genera, without exclusions.

The community structure was assessed using ShannonWeaver $\left(\mathrm{H}^{\prime}\right)$ diversity index (Shannon and Weaver, 1949), Simpson (1-D) index (Simpson, 1949), and Pielou (J) evenness (Pielou, 1975). Absolute abundance (N) and richness (S) also were estimated. Data were compared using two-way ANOVA for medians (Wilcox, 2012) once the data is non-parametric and no transformation normalized it. We also performed a nonmetric multidimensional scaling (nMDS) analysis followed by analysis of similarity (ANOSIM) (Clarke, 1993), Permutational multivariate analysis of variance (PERMANOVA) (Anderson, 2001) using Bray-Curtis distance matrix and Indicator Value (IndVal) analysis (Dufrene and Legendre, 1997) to better elucidate taxa distribution and structures amongst plants. The indicator species are defined as the most characteristic species of each group, found mainly in a single group and present in most of the samples belonging to such group.

All the analyses and graphics were performed using $\mathrm{R}$ 3.4.4 (R Core Team, 2017) and packages vegan (Oksanen et al., 2018), labdsv (Roberts, 2016), WRS2 (Mair et al., 2017) and ggplot2 (Wickham, 2009). The sampling effort and richness based on both taxonomic levels were evaluated using rarefaction curves (Sanders, 1968).

\section{Biological Activities of Endophytic Fungi Antifungal Activity}

The antifungal potential of the endophytic isolates was initially assessed by dual culture method (Badalyan et al., 2002) against the phytopathogens Colletotrichum abscissum (CA142), Phyllosticta citricarpa (LGMF06), and Fusarium verticillioides (LGMF1762). These pathogens were selected because of their importance in citrus (C. abscissum and P. citricarpa) and maize (Fusarium verticillioides) crops (Kotzé, 1981; Leslie and Summerell, 2006; Lima et al., 2011). The endophytic and pathogenic strains were previously cultured on PDA medium $\mathrm{pH}$ 5.8 , for 7-21 days. One disc ( $6 \mathrm{~mm})$ from the endophyte and one from phytopathogen were inoculated in opposites sides of the petri dish and incubated at $28^{\circ} \mathrm{C}$ for 10 days for $F$. verticillioides, 14 days for $C$. absissum and 21 days for $P$. citricarpa. As negative control, only the phytopathogen was inoculated. The experiments were performed in triplicate.

The percentage of inhibition was calculated according to Quiroga et al. (2001), comparing the growth diameter of phytopathogen on pairing plates to control plates. The antifungal activity was classified as low (50-59\%), moderate (60-69\%), and high $(\geq 70 \%)$ according to the percentage of inhibition.

\section{Antibacterial Activity}

The antibacterial activity against clinical pathogens was evaluated using overlap method according to Mapperson et al. (2014) against methicillin-sensitive Staphylococcus aureus (MSSA) (ATCC 27213), methicillin-resistant S. aureus (MRSA) (ATCC 33591), Klebsiella pneumoniae producer of the enzyme KPC (K. pneumonia carbapenemase) (BACHC-KPC), Acinetobacter baumannii (BACHAC-ABA), and Pseudomonas aeruginosa (ATCC 27853). All the pathogens were selected on the basis of their importance in human diseases and antibiotic resistance (CDC, 2013). The bacteria were cultivated for $12 \mathrm{~h}$ at $37^{\circ} \mathrm{C}$, and diluted according to the McFarland standard 0.5 scales. One $6 \mathrm{~mm}$ disk of each endophyte was inoculated into the center of the PDA plate and incubated at $28^{\circ} \mathrm{C}$ until the endophyte reaches more than $2 \mathrm{~cm}$ in diameter. The bacteria were then streaked with a cotton swab on the boards of these plates and incubated at $36^{\circ} \mathrm{C}$ for $24 \mathrm{~h}$. The experiments were performed in duplicate, and saline $(0.85 \%)$ was used as negative control. The analysis was based on the spectrum of action of endophytes: the number of pathogens inhibited; and intensity of inhibition classified as no activity $(-)$, low $(+)$, moderate $(++)$, and high $(+++)$ activity. The endophytes with higher activity and a large spectrum of action were selected for extract production.

\section{Biological Activities From Extracts of Endophytic Fungi \\ Extracts Production}

The endophytes selected in the biological activity assays were used for the preparation of extracts after fermentation in two liquid media, Malt extract (ME) (Schulz et al., 1995) and Czapeck yeast extract (CY) (Wiseman, 1975). The isolates were previously cultivated for 7 days on PDA, pH 5.8 at $28^{\circ} \mathrm{C}$. Four mycelial discs ( $6 \mathrm{~mm}$ ) were then added to $250 \mathrm{~mL}$ ( $500 \mathrm{~mL}$ Erlenmeyer flasks) of ME medium (Schulz et al., 1995) or CY medium (Wiseman, 1975), and incubated under agitation for 10 days $(180 \mathrm{rpm}$, $28^{\circ} \mathrm{C}$ ). The cultures were filtered-off on Whatmann filter and the water fraction was extracted with EtOAc $(3 \times 100 \mathrm{~mL})$. The combined organics were evaporated in vacuo at $45^{\circ} \mathrm{C}$ and diluted in methanol at $10 \mathrm{mg} / \mathrm{mL}$.

\section{Activity of Extracts Against Phytopathogens}

The extracts produced by the endophytes were evaluated against phytopathogens P. citricarpa, C. abscissum, and F. verticillioides. One hundred microliter of each extract were spread over the surface of PDA medium ( $48 \times 12 \mathrm{~mm}$ plates), using the Drigalski spatula, and one mycelial disc of each phytopathogen was inoculated in the center of the plates. As the positive control, 
the fungicide Derosal ${ }^{\circledR}(1.0 \mathrm{mg} / \mathrm{mL})$ was used for P. citricarpa and $F$. verticillioides and the fungicide Carbendazim $(0.1 \mathrm{mg} / \mathrm{mL})$ was used for C. abscissum. Methanol was used as the negative control. Plates were incubated in BOD at $28^{\circ} \mathrm{C}$ for 7 days for F. verticillioides, 10 days for C. abscissum, and 21 days for $P$. citricarpa. The growth inhibition was assessed comparing the diameter of the colony in the presence of treatment and controls (Savi, 2011). This experiment was performed in triplicate and the data were submitted to analysis of parametric variance (ANOVA) in GraphPad Prims v. 6.01.

\section{Activity of Extracts Against the Clinical Pathogens}

The antimicrobial activity of extracts produced by the endophytes was evaluated using the pathogens $S$. aureus (MSSA) (ATCC 27213) and methicillin-resistant S. aureus (MRSA) (ATCC 33591), P. aeruginosa (ATCC 27853), A. baumannii (BACHACABA), K. pneumoniae (KPC) (BACHC-KPC), Stenotrophomonas maltophilia (BACHC-SMA), Enterobacter cloacae a producer of the enzyme VIM (Verona integron-encoded metallo-blactamase) (BACHC-VIM), and Candida albicans (ATCC 10231). The pathogens were inoculated previously on $7 \mathrm{~mL}$ of $\mathrm{LB}$ broth and incubated at $37^{\circ} \mathrm{C}, 180 \mathrm{rpm}$ for $10 \mathrm{~h}$. The culture was inoculated on TSB (Tryptone Soy Broth TM Medium) plate with a cotton swab and on these plates were placed discs impregnated with each $10 \mu \mathrm{L}$ of extract. The plates were incubated at $37^{\circ} \mathrm{C}$ for $24 \mathrm{~h}$. As controls, one disc with a standard antibiotic with activity against each of the bacteria and pure methanol were used (CLSI, 2015; Savi et al., 2015). The antibacterial activity was evaluated by the measure of the inhibitory zone.

\section{RESULTS}

\section{Isolation, Morphotyping, and Phylogenetic Analyses of Endophytic Fungi From $V$. divergens and $S$. adstringens}

A high number $(1,146)$ of cultivable endophytic fungal was recovered from $V$. divergens and $S$. adstringens in collections performed in January and June 2016. Based on the morphological analysis the isolates were grouped into 124 morphotypes, 116 of them were isolated from both plants, seven were isolated exclusively from $V$. divergens, and one was isolated exclusively from $S$. adstringens. Regarding tissue specificity, five morphotypes were recovered exclusively from leaf tissues (morphotypes 29, 31, 111, and 114 were recovered exclusively from $V$. divergens and morphotype 106 was isolated exclusively from $S$. adstringens) and three morphotypes were recovered only from petiole (morphotypes 78 and 80 from $V$. divergens and morphotype 54 from $S$. adstringens) (Table S1).

The morphotypes were identified at genus and species level based on Bayesian phylogeny analysis using sequence of ITS region (Supplementary material: Figures S2-S27; Figure 2), and grouped at phylum, class and family level following the classification present at Mycobank and CABI databases (myocbank.org and speciesfungorum.org). The majority of the isolates belong to Phylum Ascomycota (95.6\% of isolates from $S$. adstringens and $96.7 \%$ from $V$. divergens) within two classes:
Dothiomycetes and Sordariomycetes. The dominant class in the phylum Ascomycota was Sordariomycetes corresponding to $61 \%$ of the isolates obtained from S. adstringens and $63 \%$ from $V$. divergens. The dominant orders in Sordariomycetes class were Diaporthales (representing $46.6 \%$ of isolates from S. adstringens and $43.4 \%$ from $V$. divergens), Xylariales ( $10.9 \%$ from $S$. adstringens and $9.8 \%$ from $V$. divergens), and Glomerellales ( $2 \%$ from S. adstringens and $4 \%$ from $V$. divergens) (Table 1). The remaining morphotypes belong to the Phylum Basidiomycota, representing $0.7 \%$ of isolates from S. adstringens and $0.9 \%$ from $V$. divergens, within Agaricomycetes class. Seven morphotypes were identified at the family level because they did not cluster with any type species of Xylariaceae family, and possibly belong to three new genera in this family (Table 1; Figure 2).

In addition, we also identified 48 taxa (Table S1), from these, 16 isolates did not cluster with any type strain of Diaporthe (Figure S11), Epicoccum (Figure S14), Fusarium (Figure S16), Hypoxylon (Figure S17), Pestalotiopsis (Figure S23), Phyllosticta (Figure S25), Pseudofusicoccum (Figure S26), Roussoella (Figure S27), and Phaeophleospora genera in the phylogeny analysis and may represent new species into these genera, however multilocus and morphological analyses are required for species description.

Nine morphotypes $(\sim 3 \%)$ did not grow in different culture media after few replications (morphotypes $8,42,72,94,95,96$, and 99), probably due to the growth-dependence of host tissues, and were characterized only at Kingdom level (fungi).

\section{Community Analysis of Endophytic Fungi From V. divergens and S. adstringens}

In June 2016, we isolated 777 (IF: 72\%) and 339 (IF: 49\%) endophytic fungi from $V$. divergens and S. adstringens, respectively (Table S1). Concerning of 777 isolates from $V$. divergens, 367 (IF: 72\%) were isolated from leaves and 410 (IF: $77 \%$ ) were isolated from petioles. For the isolates obtained from S. adstringens 174 (IF: 45\%) were obtained from leaves and 165 (IF: 43\%) were obtained from petioles (Tables S1, S2).

The analyses of genera composition showed that Diaporthe was the dominant genus in both plants $V$. divergens $(51.8 \%$ of isolates from petioles and $51.4 \%$ from leaves) and S. adstringens (49.3\% of isolates from petioles and $49.7 \%$ from leaves). The second most frequent genus was Phyllosticta (5.1 and $19.1 \%$ of isolates from petioles and leaves of $V$. divergens and 6.8 and $11.8 \%$ from petioles and leaves of $S$. adstringens) followed by Neofusicoccum (5.5 and 2.2\% from petioles and leaves of $V$. divergens and 6.8 and $7.7 \%$ from petioles and leaves of $S$. adstringens). The morphological characteristics from the dominant groups are illustrated in the Figure S1. The genera Alternaria, Coniochaeta, Neopestalotiopsis, and Paraphaeosphaeria (obtained from leaves and petioles), Daldinia and Efibula (isolated only from petioles), and Roussoella (from leaves) were recovered exclusively from $V$. divergens and Acrocalymma were isolated exclusively from leaves of S. adstringens (Figure 3).

Community structuring analyses based on genera showed no difference between plant species or plant tissues sampled 


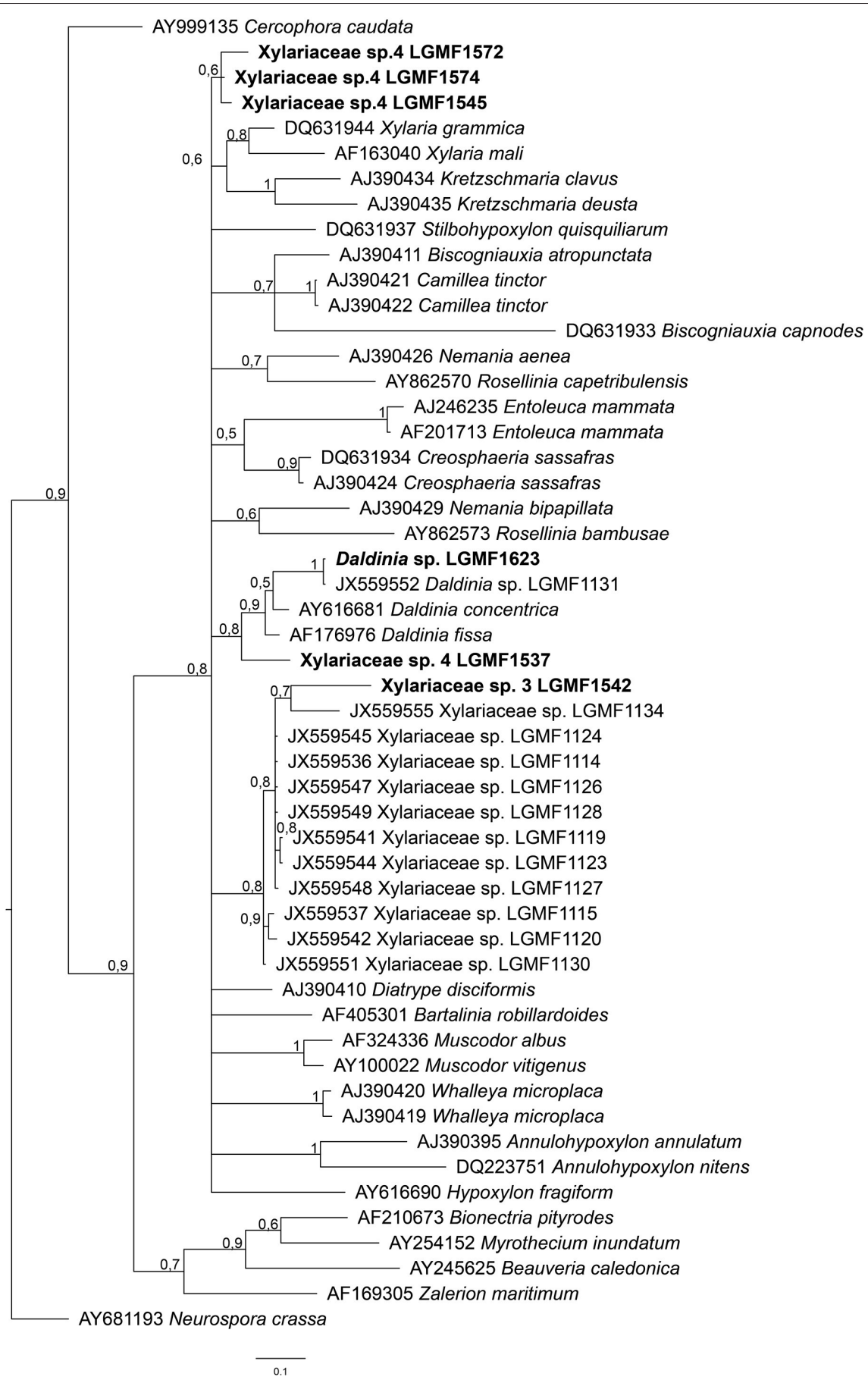

FIGURE 2 | Bayesian phylogenetic tree based on ITS partial sequence of LGMF1572, LGMF1574, LGMF1545, LGMF1613, LGMF1537, and LGMF1542 (bold) sequence of genera of Xylariaceae family. The data matrix had 52 taxa and 416 characters. The tree was rooted to: Neurospora crassa (AY681193). Scale bar shows 0.1 changes and Bayesian posterior probability values are indicated at the nodes. T: type strain.

(Table 2, Figure S28) as seen in PERMANOVA $(p>0.05)$ and nMDS (Figure 4, Tables S3, S4). On the other hand, the analysis of morphotypes composition (a lower taxonomic identification when compared to genera) presented higher abundance and richness for endophytic isolated from $V$. divergens (Table 2; Figures S28-S30) than from S. adstringens, and differences in community composition regarding to $V$. divergens plant tissues as shown by PERMANOVA $(p<0.05)$ and nMDS-ANOSIM (Figure 4B). No significance was observed in the diversity indexes $\left(\mathrm{H}^{\prime}, 1-\mathrm{D}, \mathrm{J}\right)$ for genera and morphotypes analyze in $V$. divergens and $S$. adstringens (Table 2). 
TABLE 1 | Taxonomic classification of endophytic fungi isolated from Stryphnodendron adstringens and Vochysia divergens.

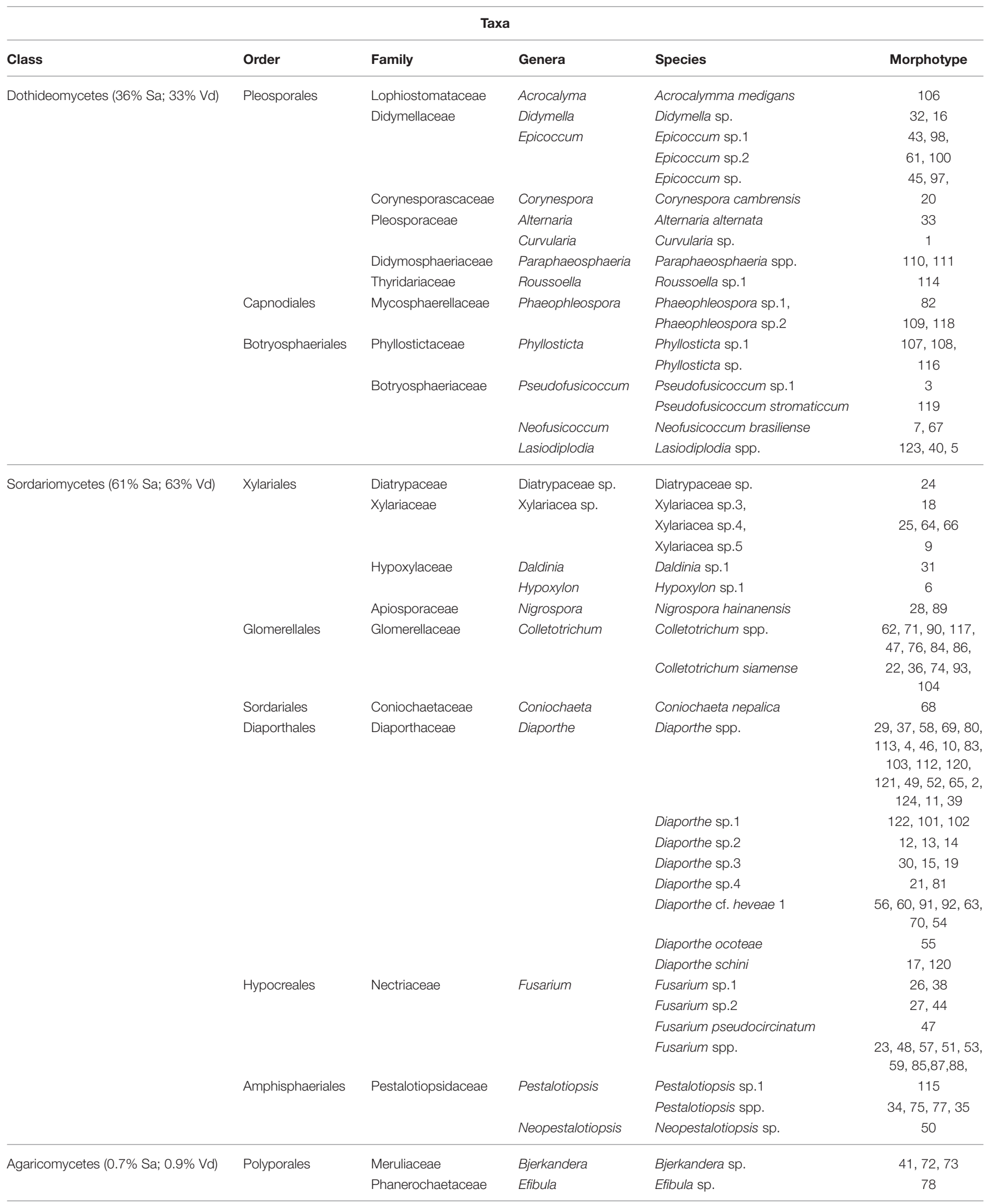

Vd, Vochysia divergens; Sa, Stryphnodendron adstringens. 


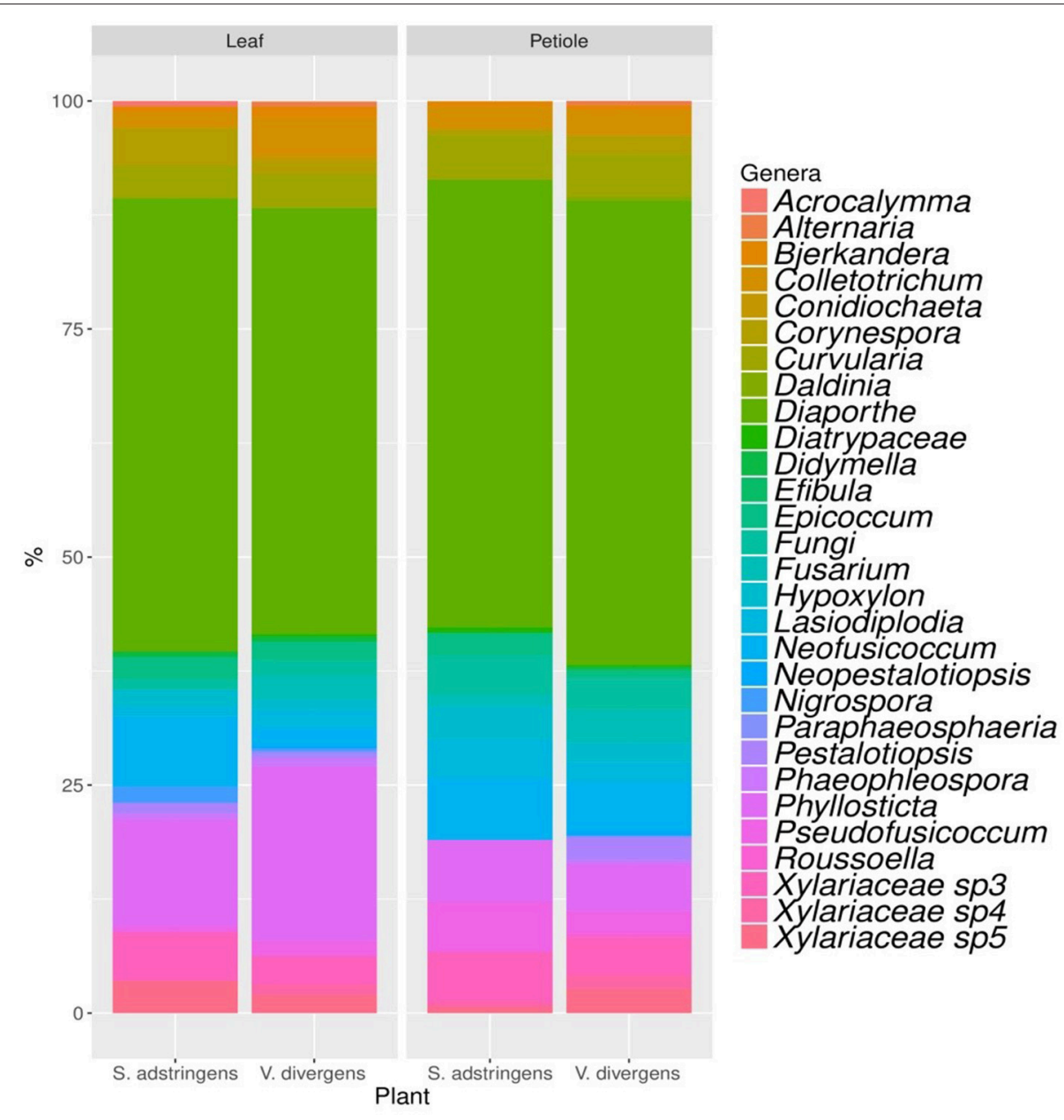

FIGURE 3 | Genera composition of endophytic community obtained from petioles and leaves of Stryphnodendron adstringens and Vochysia divergens.

\section{Biological Activity of Endophytic}

\section{Screening of Antimicrobial Activity}

Of the 124 morphotypes, 117 isolates were used in the screening for antimicrobial analysis using dual culture, since 7 morphotypes did not grow under the culture conditions used in the present study.

In the screening of antifungal activity among the 117 isolates evaluated Diaporthe sp. LGMF1530, Diaporthe cf. heveae LGMF1631, Colletotrichum siamense LGMF1604, Fusarium sp. LGMF1630, and Epicoccum sp. LGMF1641 inhibited more than $60 \%$ the mycelial growth of $P$. citricarpa and C. abscissum in the dual culture assay (Figure 5A) and were selected for the extract production. None of the isolates was able to inhibit the fungus F. verticillioides (Table S6).

The endophytes were also screened for their antimicrobial activity against clinical pathogens based on the spectrum and intensity of action. The isolates Phaeophleospora sp.2 LGMF1513, Epicoccum sp.1 LGMF1598, and Epicoccum sp.2 LGMF1600 showed high activity $(+++)$ against $S$. aureus (MSSA and MRSA). The isolates Diaporthe sp. LGMF1548 and LGMF1614, Diaporthe cf. heveae LGMF1631, Fusarium sp. LGMF1630, and Hypoxylon sp.1 LGMF1613 showed broad spectrum with moderate $(++)$ to high $(+++)$ activity against $S$. aureus (MSSA and MRSA), P. aeruginosa and A. baumannii. The isolates Neofusicoccum brasiliense LGMF1535 and Diaporthe sp. LGMF1583 showed moderate $(++)$ to high $(+++)$ activity against S. aureus (MSSA and MRSA), P. aeruginosa, A. baumannii, and K. Pneumoniae (KPC) (Table 3; Table S7).

The above-mentioned isolates were selected for secondary metabolites production in different culture media.

\section{Antifungal Activity of Extracts Produced by the Selected Endophytes Against Phytopathogens}

Eleven endophytic fungi were cultured in two different media, and seven of them produced extracts that inhibited the mycelial growth of $P$. citricarpa (Figure 5B), especially the extracts from strain Diaporthe cf. heveae LGMF1631 cultured in ME (IG: 88\%) and CY (IG:50\%) media, and extracts of Diaporthe sp. LGMF1530 (IG:42\%) and Epicoccum sp.1 LGMF1598 (IG:45\%). Extracts from four isolates inhibited the mycelial growth of $C$. abscissum (Figure 5B), highlighting the extracts from Diaporthe cf. heveae LGMF1631 produced in ME medium (Inhibition growth-IG: 
TABLE 2 | Diversity index and descriptive data for morphotypes and genus analyzed.

\begin{tabular}{|c|c|c|c|c|c|c|}
\hline Plant & Tissues & Abundance & Richness & $\mathbf{H}^{\prime}$ & Simpson (1-D) & $\mathbf{J}$ \\
\hline \multicolumn{7}{|c|}{ DIVERSITY INDEX PER MORPHOTYPE } \\
\hline V. divergens & Petiole & $22.56 \pm 11.91^{*}$ & $14.28 \pm 6.35^{\star}$ & $3.41 \pm 1.02$ & $0.85 \pm 0.22$ & $1.37 \pm 0.04$ \\
\hline \multirow[t]{2}{*}{ S. adstringens } & Petiole & $9.80 \pm 5.57$ & $7.13 \pm 4.10$ & $2.33 \pm 1.23$ & $0.69 \pm 0.31$ & $1.38 \pm 0.05$ \\
\hline & Leaf & $13.33 \pm 5.60$ & $8.33 \pm 3.26$ & $2.66 \pm 0.96$ & $0.76 \pm 0.25$ & $1.34 \pm 0.11$ \\
\hline \multirow[t]{2}{*}{ V. divergens } & Petiole & $17.52 \pm 11.99$ & $6.35 \pm 3.68$ & $1.85 \pm 0.88$ & $0.59 \pm 0.22$ & $1.12 \pm 0.22$ \\
\hline & Leaf & $13.29 \pm 11.24$ & $5.13 \pm 3.17$ & $1.64 \pm 0.76$ & $0.56 \pm 0.21$ & $1.17 \pm 0.17$ \\
\hline \multirow[t]{2}{*}{ S. adstringens } & Petiole & $10.80 \pm 6.79$ & $4.47 \pm 2.50$ & $1.51 \pm 0.90$ & $0.51 \pm 0.28$ & $1.18 \pm 0.14$ \\
\hline & Leaf & $11.27 \pm 7.40$ & $4.27 \pm 2.55$ & $1.34 \pm 0.99$ & $0.44 \pm 0.31$ & $1.10 \pm 0.17$ \\
\hline
\end{tabular}

$H^{\prime}$, Shannon-Weaver; J, Pielou evenness; * Significate differences between plants.
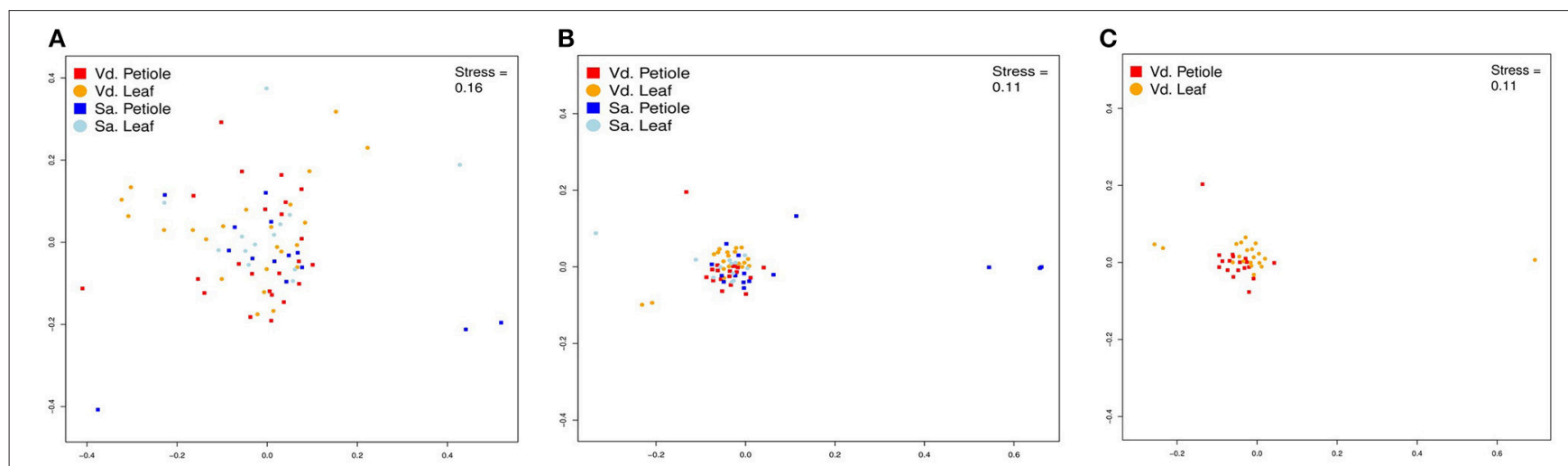

FIGURE 4 | Non-Metric Multidimensional Scaling (nMDS) of plots of fungal endophytic communities from Vochysia divergens (Vd) and Stryphnodendron adstringens (Sa). (A) NMDS plots based in genera level; (B) NMDS plots based in morphotype level; (C) NMDS plots based in morphotype level.

72\%) and in CY medium (IG: 59\%) and the extract from Epicoccum sp.2 LGMF1600 in ME medium (IG: 40\%). In the other hand, the extracts from Diaporthe cf. heveae LGMF1631 (IG: 50\%) and Hypoxylon sp.1 LGMF1613 (IG: 45\%) showed moderate activity against $F$. verticillioides (Figure 5B).

\section{Antimicrobial Activity of Extracts Produced by the Selected Endophytes Against Clinical Pathogens}

All extracts inhibited the growth of at least one clinical pathogen and the best results were obtained with extracts produced in ME medium (Table S8). The extracts from Diaporthe sp. LGMF1548 caused the highest inhibition zone against four clinical pathogens: S. aureus (MSSA) (23 mm), S. maltophilia (16 mm), K. pneumoniae (KPC) $(18 \mathrm{~mm})$, and E. cloacae $(18 \mathrm{~mm})$. Extract produced by Epicoccum sp.1 LGMF1598 showed equivalent inhibition zone against S. maltophilia $(16 \mathrm{~mm})$, and, curiously, it was the only extract that showed high activity against $A$. baumannii $(15 \mathrm{~mm})$ (Table 3; Table S8). The extract produced by $N$. brasiliense LGM1535 presented the largest inhibition zone $(23 \mathrm{~mm})$ against Methicillin-resistant S. aureus (MRSA) growth.
The second best result $(17 \mathrm{~mm})$ against MRSA was observed in the treatment with the extract of the isolate Diaporthe sp. LGMF1583, that also showed the highest inhibition zone against C. albicans $(19 \mathrm{~mm})$ and $P$. aeruginosa $(17 \mathrm{~mm})$. Table 3 showed only the highest inhibition values against each pathogen, the complete data is in the Table S8.

\section{DISCUSSION}

In order to verify if the peculiar environmental conditions found in Pantanal and Cerrado can influence the endophytic community in these biomes, we evaluated the diversity and composition of endophytic fungi in two resilient and dominant plants found in these regions, $V$. divergens of the Pantanal and $S$. adstringens of the Cerrado.

Our data revealed that $V$. divergens and $S$. adstringens are hosts of high diversity of endophytic fungi, belonging to 23 known genera, and three possible new genera in the Xylariaceae family. The number of isolates (genera and morphotypes) found in our study is larger than previous reports (Carvalho et al., 2012; Hokama et al., 2017), which may be a result of the number of 


\section{A}

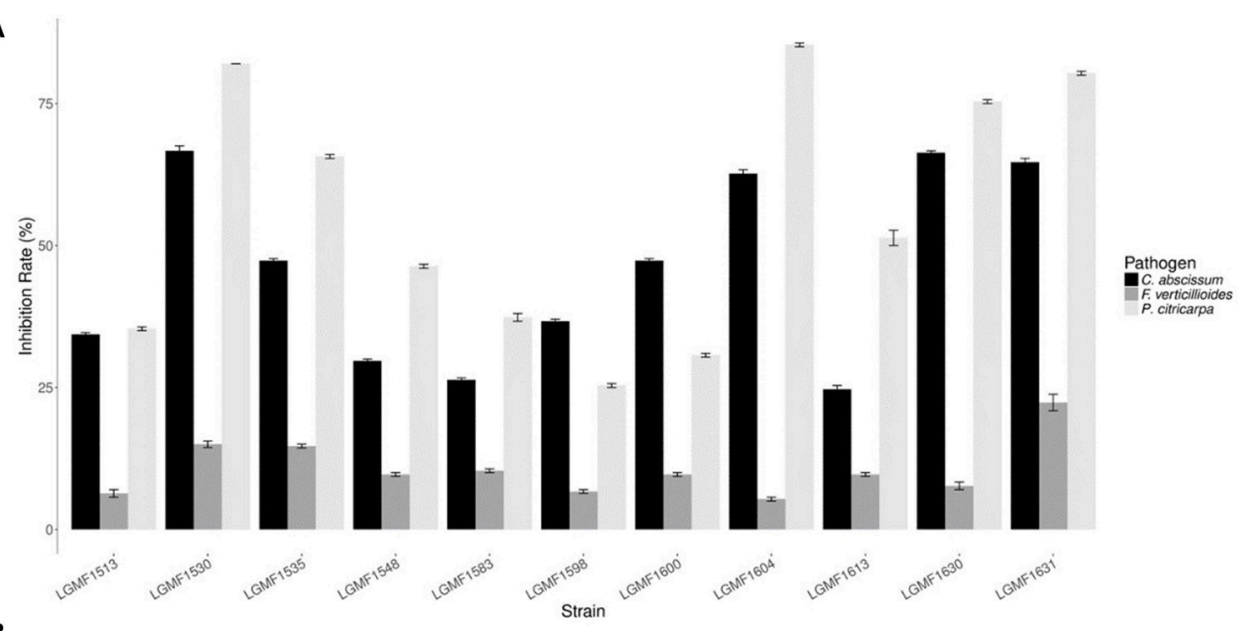

B

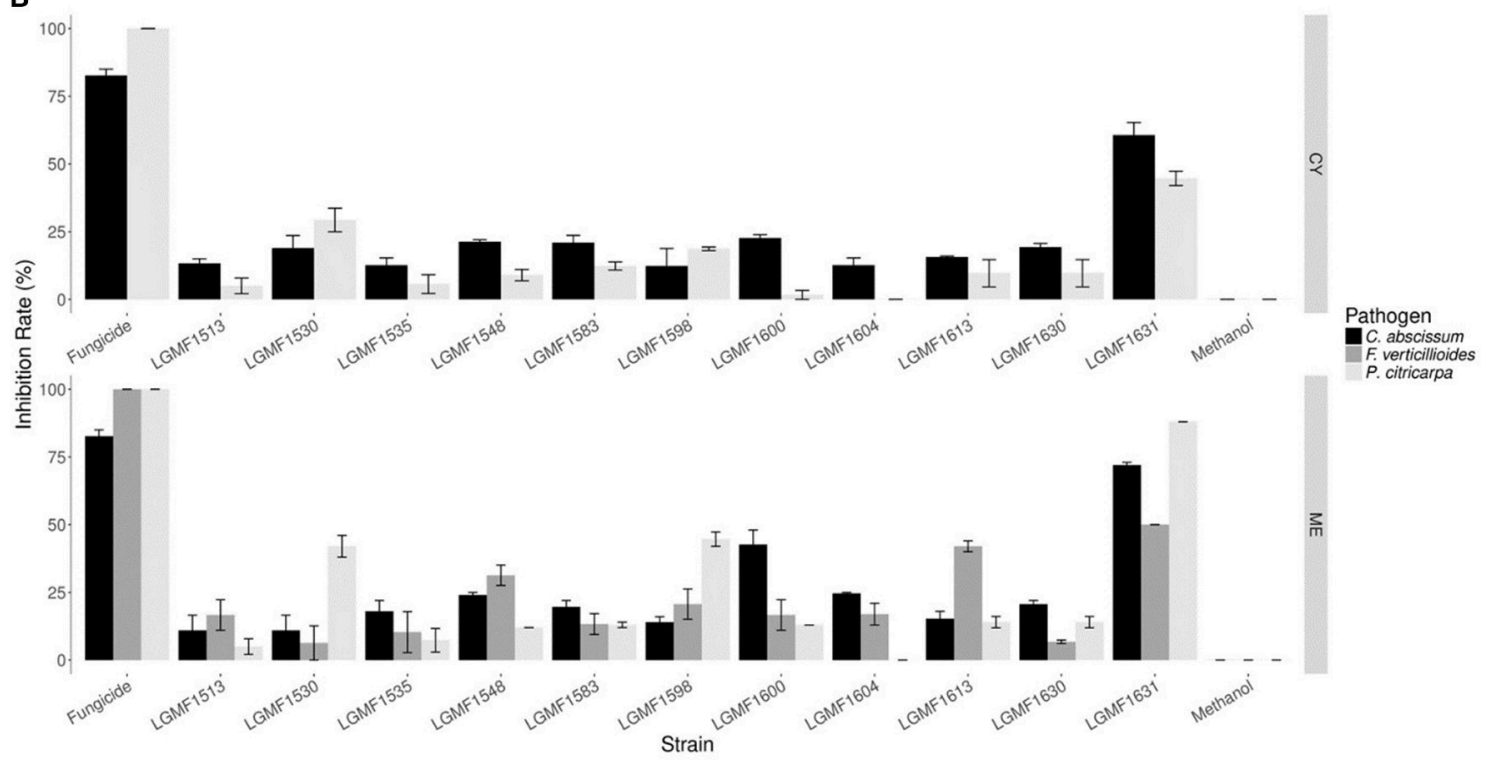

FIGURE 5 | Mean of inhibition growth (in \%) of the pathogens Colletotrichum abscissum (in black), Phyllosticta citricarpa (light gray), and Fusarium verticillioides (dark gray) in the dual culture (A). Mean of inhibition growth (in \%) of the pathogens Colletotrichum abscissum (in black), Phyllosticta citricarpa (light gray), and Fusarium verticillioides (dark gray) in presence of $100 \mu \mathrm{L}$ of extracts obtained from cultivation of endophytes in different culture media (B). Fungicide: $100 \mu \mathrm{L}$ of Carbendazim $(0.1 \mathrm{mg} / \mathrm{mL})$ was used from P. citricarpa and $100 \mu \mathrm{L}$ of Derosal $(1.0 \mathrm{mg} / \mathrm{mL})$ was used from C. abscissum and F. verticillioides.

evaluated plants or the region where the collections were carried out. Hokama et al. (2017) studied the endophytes of $V$. divergens found in another region of the Pantanal, denominated Rio Negro. The authors also obtained isolates of genera Colletotrichum, Diaporthe, and Phyllosticta and strains belonging to possible new genera of the family Xylariaceae. However, in the present work we report for the first time the genera Acrocalymma, Alternaria, Bjerkandera, Coniochaeta, Corynespora, Curvularia, Didymella, Efibula, Epicoccum, Fusarium, Hypoxylon, Lasiodiplodia, Neopestalotiopsis, Paraphaeosphaeria, Phaeophleospora, and Roussoella as endophytes of $V$. divergens (Table S1; Figures S1-S3, S6-S8, S11-S13, S15-S17, S19, S21, S23, S26). With the results obtained in this work, we are increasing knowledge about the endophytic community of these important medicinal plants.
Considering the limitations of the ITS sequences to identify some isolates at the species level, we analyzed the endophytic community using two matrix data, based on the classification of genera and morphotypes. As expected, the lower taxonomic level (morphotype) resulted in a higher resolution in the community structure. Therefore, correct identification at lower levels is of great importance for the assessment of community structure (Singh et al., 2017). The variation of the composition of the morphotypes among the analyzed hosts, $V$. divergens and $S$. adstringens, may be associated with the analyzed plant or even the environmental conditions. Pantanal plants can be severely damaged by flooding, however, $V$. divergens is highly adapted and only a short leaf falls period is reported (Da cunha Nunes et al., 2000). In this context, the endophytic community of the 


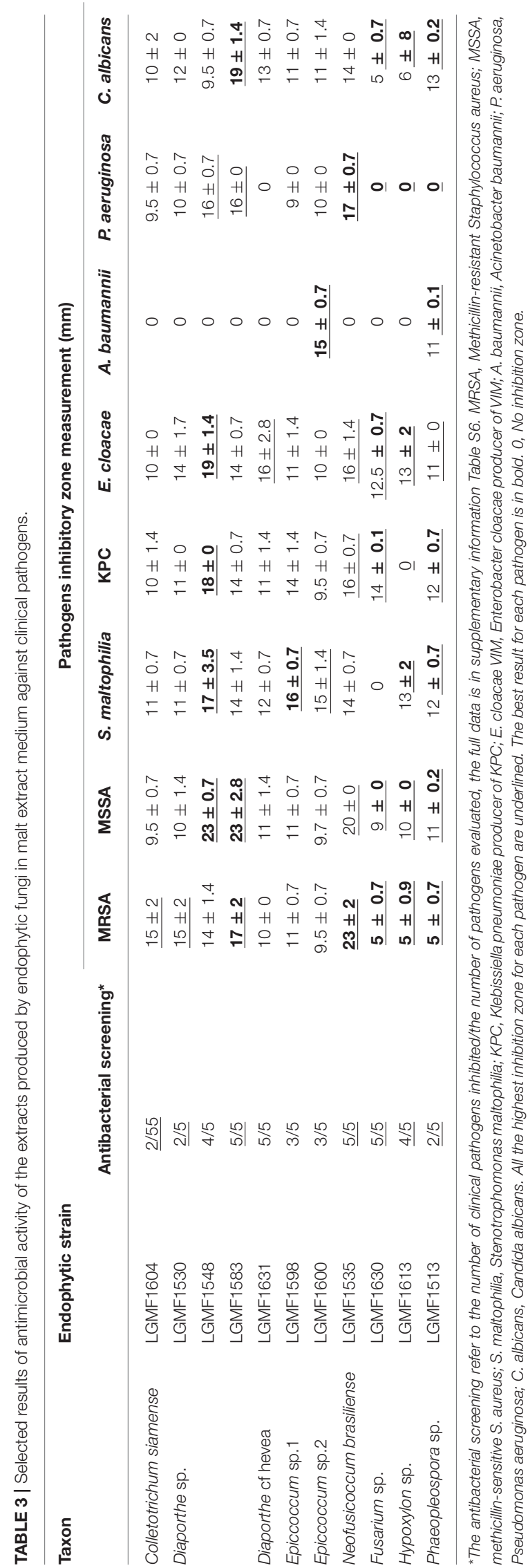

leaves of $V$. divergens do not change seasonally, providing a longer interaction between the endophytic community and the plant, both of which are adapted to the environmental conditions. In contrast, the leaves of plants found in the Cerrado can be destroyed by flames or damaged by the hot air flow (Silvério et al., 2015; Dodonov et al., 2017), which results in a shorter interaction time between the community and the plant. In addition, the region of analysis in the Cerrado is severely affected by anthropological action. Certainly, these characteristics impact the endophytic community in these biomes and may play a role in the differences observed for the composition of the morphotypes between $V$. divergens and $S$. adstringens. The community also differs among the tissues from $V$. divergens analyzed, not easily visible in the results of nMDS, but confirmed by ANOSIM (Figure 4; Tables S4, S5). The main difference in the community structure comes from a higher abundance and richness of endophytes in petioles, which may be result of a specialized endophytic microbiota (Persoh, 2015; Correia et al., 2017).

Diaporthe was the dominant genus in both plants (Figure 3; Table S1). This genus has also been described as dominant in S. adstringens by Carvalho et al. (2012) and is widely distributed in different plants of several biomes, such as the Pantanal (Hokama et al., 2017; Pietro-Souza et al., 2017), Mangrove forest (de Souza Sebastianes et al., 2013), Atlantic Rainforest (Correia et al., 2017), Cerrado and Caatinga (Ferreira et al., 2012; Lisboa et al., 2013). The ability of Diaporthe species to colonize different plants may result from the produced metabolites that bypass the plants defenses, or even by acting on host development and defense against plant pathogens (Nicoletti and Fiorentino, 2015; Santos et al., 2016; Tahir et al., 2017). Associated with the high frequency of isolation, we also found new species of Diaporthe, named as Diaporthe sp.1 (clade 1), Diaporthe sp. 2 (clade 2), (Figure S11). Gomes et al. (2013) also reported a large number of Diaporthe isolates as new species, suggesting medicinal plants in Brazil as a repository for this genus. The description of new species of Diaporthe is carried out based on the polyphasic approach, and will be carried out in a future study.

In order to associate economic value with biodiversity, bioprospecting studies have reported the biotechnological potential of endophytes against a large number of pathogens (Schulz et al., 2002; Gathage et al., 2016; Larran et al., 2016; Li et al., 2016; Hokama et al., 2017; Parpinelli et al., 2017). In this context, we investigated the antimicrobial potential of the endophytes of $V$. divergens and $S$. adstringens. Extracts produced by Diaporthe cf. heveae LGMF1631 inhibited almost $90 \%$ the mycelial growth of $P$. citricarpa the causal agent of Citrus Black Spot (CBS), a disease that affects fruits and leaves of several citrus hosts (Kotzé, 1996). The control of CBS in Brazil is based on fungicides applications, such as Derosal, and on cultural management (Kotzé, 1996; Baldassari et al., 2006). However in fruits destined to the production of juice for export, the application of the fungicide Derosal ${ }^{\circledR}$ is restricted (EPA, 2012; Fundecitrus, 2015). Diaporthe cf. heveae LGMF1631 also caused excellent inhibition (72\%) of the mycelial growth of C. abscissum, the epidemiological agent of Post-bloom Fruit Drop (PFD) (Pinho et al., 2015; Silva et al., 2016). In favorable climatic conditions, frequent rainy days during the 
bloom period, PFD can drastically reduce citrus production, reaching approximately $80 \%$ (Lima et al., 2011). Thus, the use of secondary metabolites produced by Diaporthe endophytic strains, in a biological control scenario, may be an alternative to reduce the use of fungicides in the control of citrus diseases such as CBS and PFD (Santos et al., 2016; Tonial et al., 2017).

The antimicrobial tests also revealed a high potential of endophytes to produce active secondary metabolites with broad spectrum against clinical pathogens, especially those produced by $N$. brasiliense LGMF1535, Diaporthe sp. LGMF1548 and LGMF1583 (Table 3). Significant results were obtained against MRSA (a gram-positive) and KPC (a gram-negative), two bacteria with resistance to $\beta$-lactam antibiotics, cephalosporins, monobactams, and carbapenems, respectively (Queenan and Bush, 2007). There is an urgency in finding new compounds to contain the global pandemic involving resistance to grampositive pathogens to several antibiotics (including MRSA as the main species), and which is currently one of the greatest threats to human health. In patients with bloodstream infection, for example, the range of antibiotic resistance can reach up to 82\% (CDC, 2013; Ventola, 2015; World Helth Organization, 2018)

The species belonging to the genera Diaporthe and Neopestalotiopsis are described as producing a large number of compounds with activity against several clinical pathogens, such as Escherichia coli, S. aureus, Enterococcus hirae, Micrococcus luteus, and Salmonella typhi (Specian et al., 2012). Thus, the exploration of metabolites produced by endophytes belonging to these genera and obtained from unexplored environments may represent a source for new compounds (Monciardini et al., 2014), and the extracts of the strains N. brasiliense LGMF1535, Diaporthe sp. LGMF1548 and LGMF1583 will be further explored in the chemical characterization.

\section{REFERENCES}

Alho, C. J. R., and Silva, J. S. V. (2012). Effects of severe floods and droughts on wildlife of the Pantanal Wetland (Brazil) - a review. Animals 2, 591-610. doi: 10.3390/ani2040591

Anderson, M. J. (2001). A new method for non-parametric multivariate analysis of variance. Austral. Ecol. 26, 32-46. doi: 10.1111/j.1442-9993.2001.01070.pp.x

Badalyan, S. M., Innocenti, G., and Garibyan, N. G. (2002). Antagonistic activity of xylotrophic mushrooms against pathogenic fungi of cereals in dual culture. Phytopathol. Mediter. 41, 200-225. doi: 10.14601/Phytopathol_Mediterr-1668

Baldassari, R. B., Reis, R. F., and Goes, A. (2006). Susceptibility of fruits of the 'Valencia' and 'Natal' sweet orange varieties to Guignardia citricarpa and the influence of the coexistence of healthy and symptomatic fruits. Fitopatol. Bras. 31, 4, 337-341. doi: 10.1590/S0100-41582006000400002

Carvalho, C. R., Gonçalves, V. N., Pereira, C. B., Johann, S., Galliza, I. V., Rosa, C. A., et al. (2012). The diversity, antimicrobial and anticancer activity of endophytic fungi associated with the medicinal plant Stryphnodendron adstringens (Mart.) Coville (Fabaceae) from the Brazilian savannah. Symbiosis 57, 95-107. doi: 10.1007/s13199-012-0182-2

CDC Centers for Disease Control and Prevention: Antibiotic Resistance Threats in the United States (2013). U.S. Department of Health \& Human Services. Available online at: https://www.cdc.gov/drugresistance/threat-report-2013/ pdf/ar-threats-2013-508.pdf

\section{CONCLUSIONS}

This was the first report comparing the endophytic community found in medicinal plants from the Pantanal and Cerrado biomes. Our data revealed high diversity of endophytes from both biomes, and the structure of communities at morphotype level was different between the two medicinal plants, suggesting that host species and the environmental conditions may affect the endophytic diversity. Diaporthe was the dominant genus found as endophyte in both plants. In addition, the isolates belonging to Diaporthe genus produced secondary metabolites with wide spectrum acting against different phytopathogens and microorganisms of clinical importance. Future studies will be conducted on the isolation and identification of bioactive compounds, and also a multilocus analysis will be performed for the description of the new species.

\section{AUTHOR CONTRIBUTIONS}

All authors listed have made a substantial, direct and intellectual contribution to the work, and approved it for publication.

\section{ACKNOWLEDGMENTS}

This work was supported by Fundação Araucária de Apoio e Desenvolvimento Científico e Tecnológico do Paraná - Brazil, grant 441/2012 - 23510 to CG, CNPq-Brazil grant 486016/2011-0 to CG, and CAPES-Brazil - grant to SN.

\section{SUPPLEMENTARY MATERIAL}

The Supplementary Material for this article can be found online at: https://www.frontiersin.org/articles/10.3389/fmicb. 2018.01526/full\#supplementary-material

Clarke, K. R. (1993). Non-parametric multivariate analysis of changes in community structure. Austral. J. Ecol. 18, 117-143.

CLSI (2015). Performance Standards for Antimicrobial Susceptibility Testing; Twenty-Fifth Informational Supplement. CLSI document M100-S25. Wayne, PA: Clinical and Laboratory Standards Institute.

Correia, A. M. L., Lira, S. P., Assis, M. A., and Rodrigues, A. (2017). Fungal Endophyte Communities in Begonia Species from the Brazilian Atlantic Rainforest. Curr. Microbiol. 75, 441-449. doi: 10.1007/s00284-0171400-1

Da cunha Nunes, C., Junk, W. J., Falessa, O., Costa, C. P., and Almeida, L. (2000). Influences of Dry and Flooding Periods on Phenology and the Dynamic of Seedlings and Saplings of Vochysia divergens Pohl, in the Pantanal of Poconé. German-Brazilian workshop on neotropical ecosystems - Achievements and Prospects of Cooperative Research, Hamburg, 871-874.

De Hoog, G. S., and Gerrits van den Ende, A. H. (1998), Molecular diagnostics of clinical strains of filamentous Basidiomycetes. Mycoses 41, 183-189.

de Souza Sebastianes, F. L., Romão-Dumaresq, A. S., Lacava, P. T., Harakava, R., Azevedo, J. L., de Melo, I. S., et al. (2013). Species diversity of cultivable endophytic fungi from Brazilian mangrove forests. Curr. Genet. 59, 153-166. doi: 10.1007/s00294-013-0396-8

Dodonov, P., Zanelli, C. B., and Silva-Matos, D. M. (2017). Effects of an accidental dry-season fire on the reproductive phenology of two Neotropical savanna shrubs. Brazil. J. Biol. doi: 10.1590/1519-6984.174660. [Epub ahead of print]. 
Dudeja, S. S., and Giri, R. (2014). Beneficial properties, colonization, establishment and molecular diversity of endophytic bacteria in legume and non-legume. Afr. J. Microbiol. Res. 8, 1562-1572. doi: 10.5897/AJMR2013.6541

Dufrene, M., and Legendre, P. (1997). Species assemblages and indicator species: the need for a flexible asymmetrical approach. Ecol. Monogr. 67, 345-366.

EPA (2012). United States Environmental Protection Agency. Available online at: https://www.epa.gov/

Felfili, J. M., and Fagg, C. W. (2007). Floristic composition, diversity and structure of the "Cerrado" sensu stricto on rocky soils in northern Goiás and southern Tocantins, Brazil. Rev. Bras. Bot. 30, 375-385. doi: 10.1590/S0100-84042007000300004

Ferreira, M. C., Cantrell, C. L., Wedge, D. E., Gonçalves, V. N., Jacob, M. R., Khan, S., et al. (2012). Antimycobacterial and antimalarial activities of endophytic fungi associated with the ancient and narrowly endemic neotropical plant Vellozia gigantea from Brazil. Mem. Inst. Oswaldo Cruz 112, 692-697. doi: 10.1590/0074-02760170144

Fundecitrus (2015). Doencas e Pragas: Pinta Preta. Available online at: http://www. fundecitrus.trus.com.br/doencas/pintapreta/12 (Accessed January 15, 2018).

Gathage, J. W., Lagat, Z. O., Fiaboe, K. K. M., Akutse, K. S., Ekesi, S., and Maniania, N. K. (2016). Prospects of fungal endophytes in the control of Liriomyza leafminer flies in common bean Phaseolus vulgaris under field conditions. Bio. Control 61, 741-753. doi: 10.1007/s10526-016-9761-0

Gilchrist-Saavedra, L., Fuentes-Dávila, G., Martinez-Cano, C., López-Atilano, R. M., and Duveiller, E. (2006). Practical Guide to the Identification of Selected Diseases of Wheat and Barley, 2nd Edn. Mexico: CIMMYT.

Glienke, C., Tonial, F., Figueiredo, J., Savi, D. C., Vicente, V. A., and Possiede, Y. M. (2012). "Antimicrobial activity of endophytes from Brazilian medicinal plants," in Antibacterial Agents/Book, 1st Edn, ed Varaprasad Bobbarala (Rijeka: InTech), 239-254.

Gomes, R. R., Glienke, C., Videira, S. I. R., Lombard, L., Groenewald, J. Z., and Crous, P. W. (2013). Diaporthe: a genus of endophytic, saprobic and plant pathogenic fungi. Persoonia 31, 1-41. doi: 10.3767/003158513X666844

Gos, F. M. W. R., Savi, D. C., Shaaban, K. A., Thorson,. J. S., Aluizio, R., Possied, Y. M., et al. (2017). Antibacterial activity of endophytic actinomycetes isolated from the medicinal plant Vochysia divergens (Pantanal, Brazil). Front. Microbiol. 8:1642. doi: 10.3389/fmicb.2017.01642

Hall, T. (1999). BioEdit: a user-friendly biological sequence alignment editor and analysis program for Windows 95/98/NT. Nucl. Acids Symp. Ser. 41, 95-98.

Hokama, Y., Savi, D. C., Assad, B., Aluizio, R., Gomes-Figueiredo, J., Adamoski, D., et al. (2017). "Endophytic fungi isolated from Vochysia divergens in the pantanal, Mato Grosso do Sul: diversity, phylogeny and biocontrol of Phyllosticta citricarpa" in Endophytic Fungi: Diversity, Characterization and Biocontrol, 4th Edn, ed E. Hughes (Hauppauge, NY: Nova), 1-25.

Hyde, K. D., and Soytong, K. (2008). The fungal endophyte dilemma. Fungal Divers. 33:163-173.

IBGE (2004). Mapa de Biomas do Brasil, Primeira Aproximação. Rio de Janeiro: IBGE. Available online at: www.ibge.gov.br.

Junk, W. J., Bayley, P. B., and Sparks, R. E. (1989). The flood pulse concept in river-floodplain systems. Can. J. Fish. Aquat. Sci. 106, 110-127.

Junk, W. J., Cunha, C. N., Wanzen, K. M., Petermann, P., Strussmann, C., and Marques, M. I. (2006). Biodiversity and its conservation in the Pantanal of Mato Grosso Brazil. Aquat. Sci. 68, 278-309. doi: 10.1007/s00027-006-0851-4

Katoh, K., and Toh, H. (2008). Recent developments in the MAFFT multiple sequence alignment program. Brief. Bioinform. 9, 286-298. doi: 10.1093/bib/bbn013

Köberl, M., Schmidt, R., Ramadan, E. M., Bauer, R., and Berg, G. (2013). The microbiome of medicinal plants: diversity and importance for plant growth, quality and health. Front. Microbiol. 4:400. doi: 10.3389/fmicb.2013.00400

Kotzé, J. M. (1981). Epidemiology and control of citrus black spot in South Africa. Plant Diseas. 65, 945-950.

Kotzé, J. M. (1996). History and epidemiology of Citrus Black Spot in South Africa. Proc. Int. Soc. Citric. 2, 1296-1299.

Kumar, S., Stecher, G., and Tamura, K. (2015). MEGA7: Molecular Evolutionary Genetics Analysis version 7 for bigger datasets. Mol. Biol. Evol. 33, 1870-1874. doi: 10.1093/molbev/msw054

Larran, S., Simón, M. R., Moreno, M. V., Siurana, M. S., and Perelló, A. (2016). Endophytes from wheat as biocontrol agents against tan spot disease. Biol. Control 92, 17-23. doi: 10.1016/j.biocontrol.2015.09.002
Leslie, J. F., and Summerell, B. A. (2006). Fusarium Laboratory Manual. Iowa: Blackwell Publishing.

Li, J. L., Sun, X., Chen, L., and Liang-Dong, G. (2016). Community structure of endophytic fungi of four mangrove species in Southern China. Mycol 7, 180-190. doi: 10.1080/21501203.2016.1258439

Lima, W. G., Spósito, M. B., Amorim, L., Gonçalves, F. P., and Melo Filho, P. A. (2011). Colletotrichum gloeosporioides, a new causal agent of citrus post-bloom fruit drop. Eur. J. Plant Pathol. 131, 157-165. doi: 10.1007/s10658-011-9795-1

Lisboa, H. C., Biasetto, C. R., de Medeiros, J. B., Âraújo, Â. R., Silva, D. H., Teles, H. L., et al. (2013). Endophytic fungi producing of esterases: Evaluation in vitro of the enzymatic activity using pH indicator. Braz. J. Microbiol. 44, 923-926. doi: 10.1590/S1517-83822013005000067

Mair, P., Schoenbrodt, F., and Wilcox, R. (2017). WRS2: Wilcox Robust Estimation and Testing. Cambridge.

Mapperson, R. R., Kotiw, M., Davis, R. A., and Dearnaley, J. D. (2014). The diversity and antimicrobial activity of Preussia sp. endophytes isolated from Australian dry rainforests. Curr. Microbiol. 68, 30-37. doi: $10.1007 / \mathrm{s} 00284-013-0415-5$

Monciardini, P., Iorio, M., Maffioli, S., Sosio, M., and Donadio, S. (2014). Discovering new bioactive molecules from microbial sources. Microbiol. Biotechnol. 7, 209-220. doi: 10.1111/1751-7915.12123

Murali, T. S., Suryanarayanan, T. S., and Venkatesan, G. (2007). Fungal endophyte communities in two tropical forest of southern India: diversity and host affiliation. Mycol. Progr. 6, 191-199. doi: 10.1007/s11557-007-0540-2

Myers, N., Mittermeier, R. A., Mittermeier, C. G., da Fonseca, G. A. and Kents, J. (2000). Biodiversity hotspots for conservation priorities. Nature 403, 853-858. doi: $10.1038 / 35002501$

Nicoletti, R., and Fiorentino, A. (2015). Plant bioactive metabolites and drugs produced by endophytic fungi of Spermatophyta. Agriculture 5, 918-970. doi: 10.3390/agriculture 5040918

Oksanen, J. F., Guillaume Blanchet, M. F., Roeland, K., Pierre, L., Dan McGlinn, P. R., Minchin, R. B., et al. (2018). vegan: Community Ecology Package. R package Version 2, 4-6. Available online at: https://CRAN.R-project.org/package=vegan

Oliveira-Filho, A. T., and Ratter, J. A. (2002). "Vegetation physiognomies and woody flora of the cerrado biome," in The Cerrados of Brazil: Ecology and Natural History of a Neotropical Savanna, eds P. S. Oliveira and R. J. Marquis (New York, NY: Columbia University Press), 91-120.

Parpinelli, B. A. S., Siqueira, K. A., Kellner-Filho, L. C., Pimenta, L. P., Costa, R. M., Parreira, R. L. T., et al. (2017). Effect of endophytic fungal associations on the chemical profile of in vitro Vochysia divergens seedlings. J. Braz. Chem. Soc. 28, 2375-2381. doi: 10.21577/0103-5053.20170091

Persoh, D. (2015). Plant-associated fungal communities in the light of metagenomics. Fungal Diver. 75, 1-25. doi: 10.1007/s13225-015-0334-9

Petrini, O. (1986). Taxonomy of Endophytic Fungi of Aerial Plant Tissues. Microbiology of the Phyllosphere. Cambridge: Cambridge University Press, $175-187$.

Petrini, O., Stone, J., and Carroll, F. E. (1982). Endophytic fungi in evergreen shrubs in western Oregon: a preliminary study. Can. J. Bot. 60, 789-796. doi: $10.1139 / \mathrm{b} 82-102$

Pielou, E. C. (1975). Ecological Diversity. New York, NY: John Wiley and Sons.

Pietro-Souza, W., Mello, I. S., Vendruscullo, S. J., Da Silva, G. F., Da Cunha, C. N., White, J. F., et al. (2017). Endophytic fungal communities of Polygonum acuminatum and Aeschynomene fluminensis are influenced by soil mercury contamination. PLoS ONE 12:7. doi: 10.1371/journal.pone.0182017

Pinho, D. B., Lopes, U. P., Pereira, O. L., Silveira, A. L., and de Goes, A. (2015). Colletotrichum abscissum Pinho and O.L. Pereira, sp. nov. Persoonia 34, 236237. doi: 10.3767/003158515X688433

Porras-Alfaro, A., and Bayman, P. (2011). Hidden fungi, emergent properties: endophytes and microbiomes. Ann. Rev. Phytopathol. 49, 291-315. doi: 10.1146/annurev-phyto-080508-081831

Queenan, A. M., and Bush, K. (2007). Carbapenemases: the versatile $\beta$-lactamases. Clin. Microbiol. Rev. 20, 440-458. doi: 10.1128/CMR.00001-07

Quiroga, E. N., Sampietro, A. R., and Vattuone, M. (2001). Screening antifungal activity of selected medicinal plants. J. Ethnopharmacol. 74, 89-96. doi: 10.1016/S0378-8741(00)00350-0

R Core Team (2017). R: A Language and Environment for Statistical Computing. Vienna: R Foundation for Statistical Computing. Available online at: https:// www.R-project.org/ 
Raeder, J., and Broda, P. (1985). Rapid Preparation of DNA from filamentous fungi. Let. Appl. Microbiol. 1, 17-20. doi: 10.1111/j.1472-765X.1985.tb01479.x

Roberts, D. (2016). labdsv: Ordination and Multivariate Analysis for Ecology. $R$ Package Version 1.8-0. Available online at: https://CRAN.R-project.org/ package $=$ labdsv

Ronquist, F., Teslenko, M., Van Der Mark, P., Ayres, D. L., and Darling, A. (2011). MrBayes 3.2: efficient Bayesian phylogenetic inference and model choice acrossa large model space. Syst. Biol. 61, 539-542. doi: 10.1093/sysbio/sys029

Sanders, H. L. (1968). Marine benthic diversity: a comparative study. Am. Nat. 102, 925-243. doi: $10.1086 / 282541$

Santos, P. J. C., Savi, D. C., Gomes, R. R., Goulin, E. H., da costa Senkiv, C., Tanaka, F. A., et al. (2016). Diaporthe endophytica and D. terebinthifolii from medicinal plants for biological control of Phyllosticta citricarpa. Microbiol. Res. 186, 153-160. doi: 10.1016/j.micres.2016.04.002

Santoyo, G., Moreno-Hagelsieb, G., Del Carmen Orozco-Mosqueda, M., and Glick, B. R. (2016). Plant growth-promoting bacterial endophytes. Microbiol. Res. 183, 92-99. doi: 10.1016/j.micres.2015.11.008

Savi, D. C. (2011). Biodiversidade E Bioprospecção De Actinomicetos Da Planta Vochysia divergens (Cambará). Dissertação, Universidade Federal Do Paraná.

Savi, D. C., Aluizio, R., Galli-Terasawa, L., Kava, V., and Glienke, C. (2016). 16SgyrB- rpoB multilocus sequence analysis for species identification in the genus Microbispora. Ant. van Leeuw. 109, 801-815. doi: 10.1007/s10482-016-0680-y

Savi, D. C., Haminiuk, C. W. I., Sora, G. T. S., Adamoski, D. M., Kensiki, J., Winnischofer, S. M. B., et al. (2015). Antitumor, antioxidant and antibacterial activities of secondary metabolites extracted by endophytic actinomycetes isolated from Vochysia divergens. Int. J. Pharm. Chem. Biol. Sci. 5, 347-356.

Savi, D. C., Shaaban, K. A., Gos, F. M. W. R., Ponomareva, L. V., Thorson,. J. S., Glienke, C., et al. (2018). Phaeophleospora vochysiae Savi and Glienke sp. nov. isolated from Vochysia divergens Found in the Pantanal, Brazil, produces bioactive secondary metabolites. Sci. Rep. 8:3122. doi: 10.1038/s41598-018-21400-2

Schulz, B., Boyle, C., Draeger, S., Aust, H. J., Römmert, A. K., and Krohn, K. (2002). Endophytic fungi: a source of novel biologically active secondary metabolites. Mycol. Res. 106:996-1004. doi: 10.1017/S0953756202006342

Schulz, K. F., Chalmers, I., Hayes, R. J., and Altman, D. G. (1995). Empirical evidence of biasdimensions of methodological quality associated with estimates of treatment effects in controlled trials. JAMA 273, 408-412.

Shannon, C. E., and Weaver, W. (1949). The Mathematical Theory of Communication. Urbana, IL: University of Illinois Press.

Silva, A. O., Savi, D. C., Gomes, F. B., Gos, F. M. W. R., Silva, G. J., and Glienke, C. (2016). Identification of Colletotrichum species associated with postbloom fruit drop in Brazil through GAPDH sequencing analysis and multiplex PCR. Eur. J. Plant Pathol. 147, 731-748. doi: 10.1007/s10658-016-1038-z

Silva, J. M. C., and Bates, J. M. (2002). Biogeographic patterns and conservation in the South American Cerrado: a tropical Savanna hotspot. BioScience 52, 225-233. doi: 10.1641/0006-3568(2002)052[0225:BPACIT]2.0.CO;2

Silvério, D. V., Pereira, O. R., Mews, H. A., Maracahipes-Santos, L. S., Josias, O., and Lenza, E. (2015). Surface fire drives short-term changes in the vegetative phenology of woody species in a Brazilian savanna. Biot. Neotropica 15-3. doi: 10.1590/1676-0611-BN-2014-0077

Simpson, E. H. (1949). Measurement of diversity. Nature 163:688.
Singh, D. K., Sharma, V. K., Kumar, J., Mishra, A., Verma, S. K., Sieber, T. N., et al. (2017). Diversity of endophytic mycobiota of tropical tree Tectona grandis Linn.f.: Spatiotemporal and tissue type effects. Sci. Rep. 7:3745. doi: 10.1038/s41598-017-03933-0

Sousa, C. P., Serrano, N. F. G., and Lacava, P. T. (2017). "Endophytic microorganisms of the tropical savannah: a promising source of bioactive molecules," in Diversity and Benefits of Microorganisms from the Tropics, eds J. de Azevedo and M. Quecine (Cham: Springer), 57-70.

Specian, V., Sarragiotto, M. H., Pamphile, J. A., and Clemente, E. (2012). Chemical characterization of bioactive compounds from the endophytic fungus Diaporthe helianthi isolated from Luehea divaricata. Braz. J. Microbiol. 34, 1174-1182. doi: 10.1590/S1517-838220120003000045

Tahir, H. A., Gu, Q., Wu, H., Niu, Y., Huo, R., and Gao, X. (2017). Bacillus volatiles adversely affect the physiology and ultra-structure of Ralstonia solanacearum and induce systemic resistance in tobacco against bacterial wilt. Sci. Rep. 7:40481. doi: 10.1038/srep40481

Tamura, K., Peterson, D., Peterson, N., Stecher, G., Nei, M., and Kumar, S. (2013). MEGA5: molecular evolutionary genetics analysis using maximum likelihood, evolutionary distance, and maximum parsimony methods. Mol. Biol. Evol. 28, 2731-2739. doi: $10.1093 / \mathrm{molbev} / \mathrm{msr} 121$

Tonial, F., Maia, B. H. L. N. S., Savi, D. C., vicente, V. A., Gomes, R. R.,(2017). Biological activity of Diaporthe terebinthifolii extracts against Phyllosticta citricarpa. FEMS Microbiol. Lett. 364:fnx026. doi: 10.1093/femsle/fnx026

Ventola, C. L. (2015). The antibiotic resistance crisis. PT 40, 277-283.

Vieira, M. L., Johann, S., Hughes, F. M., Rosa, C. A., and Rosa, L. H. (2014), The diversity and antimicrobial activity of endophytic fungi associated with medicinal plant Baccharis trimera (Asteraceae) from the Brazilian savannah. Can. J. Microbiol. 60, 847-856. doi: 10.1139/cjm-2014-0449

White, T. J., Bruns, T., Lee, J., and Taylor, J. (1990). "Amplification and direct sequencing of fungal ribosomal RNA genes for phylogenetics," in PCR Protocols: A Guide to Methods and Applications, eds M. A. Innis, D. H. Gelfand, J. J. Sninsky, and T. J., White (San Diego, CA: Academic Press), 315-322.

WHO (2018). World Helth Organization. Available online at: from http://www. who.int/antimicrobial-resistance/en.

Wickham, H. (2009). ggplot2: Elegant Graphics for Data Analysis. New York NY: Springer-Verlag.

Wilcox, R. (2012). Introduction to Robust Estimation and Hypothesis Testing, 3rd Edn. Cambridge: Elsevier.

Wiseman, A. (1975). Handbook of Enzyme Biotechnology. Chichester: John Wiley and Sons Ltd.

Conflict of Interest Statement: The authors declare that the research was conducted in the absence of any commercial or financial relationships that could be construed as a potential conflict of interest.

Copyright (c) 2018 Noriler, Savi, Aluizio, Palácio-Cortes, Possiede and Glienke. This is an open-access article distributed under the terms of the Creative Commons Attribution License (CC BY). The use, distribution or reproduction in other forums is permitted, provided the original author(s) and the copyright owner(s) are credited and that the original publication in this journal is cited, in accordance with accepted academic practice. No use, distribution or reproduction is permitted which does not comply with these terms. 